\title{
SELECTIVE SPECTROPHOTOMETRIC DETERMINATION OF FENOTEROL BY THREE DIFFERENT METHODS.
}

\author{
Monir A. Amin, Fathy M. Salama, Mohamed W. Ibrahim, Alsediq A. Obeid* and \\ Samir M. Morshedy \\ Analytical Chemistry Department, Faculty of Pharmacy, Al-Azhar University, Cairo, Egypt. \\ * Department of Chemistry, Faculty of Science, Misurata University, Libya.
}

\begin{abstract}
:
Three simple and selective spectrophotometric methods were developed for the quantitative determination of Fenoterol in pure forms as well as in its pharmaceutical formulation. Method [A] Involves the coupling of the drug as phenolic compound with the diazonium salts of four amines, namely, Benzocaine (BZC), sulphadiazine (SDZ), sulphacetamide (SCM) and sulphanilic acid (SPA) forming red azodyes absorbed at 526, 514, 512 and $513 \mathrm{~nm}$, respectively. Beer's law was obeyed in the concentration ranges of 10-70, 6-42, 4-28 and 3.5-24.5 $\mu \mathrm{g} \mathrm{ml}^{-1}$ for the four reagents, respectively. Method [B] is based on reaction of Fenoterol with cobalt thiocyanate, where by a sparingly soluble blue ion-pair complex is formed. This complex is extracted by toluene and spectrophotometrically measured at $619 \mathrm{~nm}$. Good linearity was obtained in the range of $10-70 \mu \mathrm{g} \mathrm{ml}^{-1}$. Method [C] is based on the reduction of iron (III) by Fenoterol in acid medium and subsequent interaction of iron (II) with ferricyanide to form Prussian blue. The product exhibits absorption maximum at $730 \mathrm{~nm}$. Beer's law was obeyed in the concentration range of 1.5 $10.5 \mu \mathrm{g} \mathrm{ml}^{-1}$. The reaction conditions for described methods were studied and optimized. The proposed methods were applied to the determination of Fenoterol in pharmaceutical formulation and the results demonstrate that the methods are equally accurate and precise as the reported methods found from the $\mathrm{t}$ and $\mathrm{F}$ values. The reliability of the methods was established by recovery studies using standard addition technique.
\end{abstract}

\section{INTRODUCTION}

Fenoterol (Fig. 1) is a direct acting sympathomimetic agent with predominantly betaadrenergic activity and a selective action on $\beta_{2}$ receptors. It is used as bronchodilator, with its bronchodilating action being relatively more prominent than its effect on the heart. It is used in the treatment of bronchial asthma, prevention of exercise-induced bronchspasm and in the management of premature labour (Kathleen, 1999).

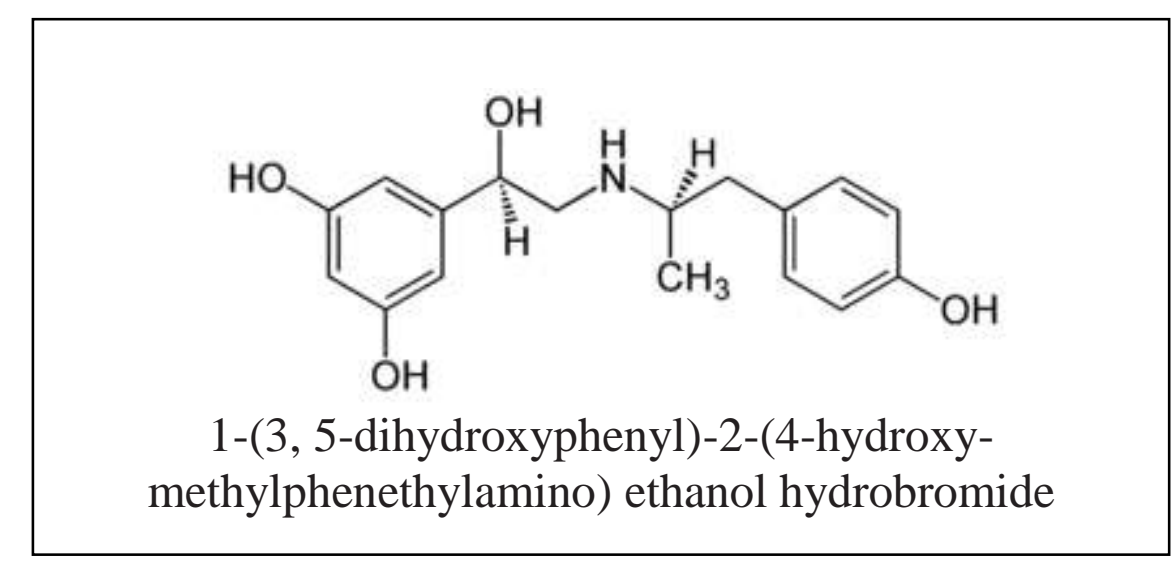

Fig.1 
Different methods have been reported for the determination of Fenoterol such as spectrophotometric (El-Shabrawy et al., 2003; Negussie et al., 2004; Zamuner et al., 2008), spectrofluorimetric (Manal, 2007; El-Tarras et al., 2005), HPLC (Danuta et al., 2008; Ingolfe et al., 2002), LC-MS (Hee Seung, et al., 2008), Capillary zone electrophoresis (Somsak and Proespichaya, 2008), and electrochemical methods (Belal et al., 2000). The aim of the present study is to develop new, simple, and accurate quantitative methods for determination of fenoterol in both pure and pharmaceutical forms.

\section{EXPERIMENTAL}

\section{Pure sample}

Fenoterol hydrobromide (99.67\%); was kindly supplied by Chemical Industries Development Company, (CID), Giza, Egypt.

\section{Market sample}

Berotec $^{\circledR}$ Tablets: Product of Chemical Industries Development Company (CID) Cairo, Egypt. Batch No. (503104), labeled to contain $0.5 \mathrm{mg}$ Fenoterol hydrobromide per tablet and purchased from local pharmacies.

\section{Chemicals and Reagents:}

All reagents used were of analytical grade, solvents were of spectroscopic grade and water was freshly double-distilled.

- Sodium hydroxide, hydrochloric acid, ethanol, cobalt chloride, ammonium thiocyanate, toluene, chloroform, methylene chloride, benzene, ferric chloride, potassium ferricyanide and methanol (El-Nasr Company, Egypt) (ADWIC).

- Sodium nitrite (Winlab-UK) $1 \%$ aqueous solution.

- Sodium hydroxide $0.2 \mathrm{~N}$ and $1 \mathrm{~N}$ aqueous solution.

- Benzocain $0.1 \%$ in ethanol (Sigma, U.S.A).

- Hydrochloric acid $0.1 \mathrm{~N}$ aqueous solution.

- Sulphadiazine $0.1 \%$ in ethanolic $0.1 \mathrm{~N} \mathrm{HCl}$ (Sigma, U.S.A)

- Sulphacetamide $0.1 \%$ in ethanol (Sigma, U.S.A)

- Sulphuric acid $1 \mathrm{M}$ and $10 \mathrm{M}$ aqueous solution (Merck-Germany).

- Sulphanilic acid 1\% aqueous solution, (ADWIC, Egypt)

- Cobalt thiocyanate (prepared by mixing 56.25 gm NH $\mathrm{NCN}_{4} \mathrm{SC}$ with $13.80 \mathrm{gm} \mathrm{CoCl}_{2}$ in $\mathrm{H}_{2} \mathrm{O}$ to give $100 \mathrm{ml}$ of the solution (Nerin et al., 1985).

- Ferric chloride $0.2 \%$ and potassium ferricyanide $0.2 \%$ aqueous solutions.

\section{Apparatus:}

Shimadzu, UV-Vis 1650 PC spectrophotometer, equipped with $10 \mathrm{~mm}$ matched quartz cells.

\section{Standard solutions:}

For method $\mathbf{A}$ and $\mathbf{C}$, stock solutions of Fenoterol $\left(1 \mathrm{mg} \mathrm{ml}^{-1}\right)$ were prepared by dissolving $100 \mathrm{mg}$ powder of Fenoterol in $100 \mathrm{ml}$ water. For method B the stock solutions of Fenoterol $\left(1 \mathrm{mg} \mathrm{ml}^{-1}\right)$ were prepared by dissolving $100 \mathrm{mg}$ powder in $100 \mathrm{ml}$ methanol. Solutions with different concentrations were prepared from the stock solution by suitable dilutions. 


\section{Procedure:}

\subsection{Method A (Diazo-coupling technique):}

\subsubsection{Construction of calibration graphs:}

In a series of $10 \mathrm{ml}$ volumetric flasks a volume of $0.5 \mathrm{ml}$ of amine compounds $0.1 \%$ BZC, $0.1 \%$ SDZ, $0.1 \%$ SCM and $1 \%$ SPA was mixed with $0.5 \mathrm{ml}$ of $0.1 \mathrm{~N}$ hydrochloric acid and $1 \mathrm{ml}$ of $\mathrm{NaNO}_{2}$ solution $(1 \%)$ and the mixture was left to stand for $10 \mathrm{~min}$. different aliquots of the standard solution of Fenoterol equivalent to $(100-700 \mu \mathrm{g}),(60-420 \mu \mathrm{g}),(40-$ $280 \mu \mathrm{g})$ and $(35-245 \mu \mathrm{g})$ were added to the diazo-reagent formed by BZC, SDZ, SCM and SPA respectively. The calibration curve representing the relationship between the absorbance and the corresponding concentrations were constructed and the corresponding regression equations were computed.

Then $0.5 \mathrm{ml}$ of $0.2 \mathrm{~N}$ sodium hydroxide was added dropwise to each flask and the volume was adjusted to the mark with ethanol, the absorbance of the red coloured formed was measured at 526, 514, 512 and $513 \mathrm{~nm}$ for BZC, SDZ, SCM and SPA acid respectively.

$\underline{\text { N.B. }}$. In case of sulphadiazine, hydrochloric acid was omitted where the amine dissolved in ethanolic $0.1 \mathrm{~N} \mathrm{HCl}$ and in case of sulphanilic acid hydrochloric acid was not necessary as the amine is acidic in nature.

\subsubsection{Determination of the stoichiometry of the reaction by Molar ratio method (Rose, 1964)}

In a series of $25 \mathrm{ml}$ volumetric flasks, different volumes $(1-10 \mathrm{ml})$ of BZC solution $\left(4.12 \times 10^{-5} \mathrm{M}\right)$, SDZ solution $\left(2.47 \times 10^{-5} \mathrm{M}\right)$, SCM solution $\left(1.64 \times 10^{-5} \mathrm{M}\right)$ and SPA solution $\left(1.44 \times 10^{-5} \mathrm{M}\right)$ were mixed with $1 \mathrm{ml}$ of $0.1 \mathrm{~N}$ hydrochloric acid (in case of BZC and $\mathrm{SCM}$ ) and $2 \mathrm{ml}$ of sodium $\mathrm{NaNO}_{2}$ solution (1\%) the mixture were left to stand for 10 minutes, $1 \mathrm{ml}$ of Fenoterol solution $\left(4.12 \times 10^{-5} \mathrm{M}\right),\left(2.47 \times 10^{-5} \mathrm{M}\right),\left(1.64 \times 10^{-5} \mathrm{M}\right)$ and $\left(1.44 \times 10^{-5} \mathrm{M}\right)$, respectively were added to each flask followed by $1 \mathrm{ml}$ of $0.2 \mathrm{~N}$ sodium hydroxide, again stay for 5 minute, complete the volume to the mark with water and measure the absorbencies at their corresponding $\lambda_{\max }$.

\subsection{Method B: (Ion-pair technique)}

\subsubsection{Construction of calibration graphs}

Aliquots of standard solution equivalent to $(100-700 \mu \mathrm{g})$ were transferred quantitatively to $50 \mathrm{ml}$ separating funnels followed by $4 \mathrm{ml}$ of cobalt thiocyanate reagent. The solutions were mixed and the formed blue coloured complexes were extracted with 10 $\mathrm{ml}$ of toluene. The organic extract was collected in $10 \mathrm{ml}$ volumetric flask and completed to volume with toluene. Absorbencies were measured at $619 \mathrm{~nm}$. The calibration curve representing the relationship between the absorbance and the corresponding concentrations were constructed and the corresponding regression equations were computed.

\subsubsection{Determination of the stoichiometry of the reaction by Molar ratio method (Rose, 1964):}

In a series of $50 \mathrm{ml}$ separating funnels, deferent volumes $(0.5-5 \mathrm{ml})$ of cobalt thiocyanate reagent $\left(1.64 \times 10^{-5} \mathrm{M}\right)$ were added to $1 \mathrm{ml}$ Fenoterol $\left(1.64 \times 10^{-5} \mathrm{M}\right)$. The solutions were mixed and the formed blue coloured complexes were extracted with $10 \mathrm{ml}$ of toluene. The organic extract was collected in $10 \mathrm{ml}$ volumetric flask and completed to volume with toluene and the absorbances were measured at $619 \mathrm{~nm}$. The calibration curve representing the relationship between the absorbance and the corresponding concentrations were constructed and the corresponding regression equations were computed. 


\subsection{Method C: (Prussian blue technique):}

\section{Construction of calibration graphs:}

Into a series of $10 \mathrm{ml}$ volumetric flasks different aliquots $(15-105) \mu \mathrm{g} \mathrm{ml}^{-1}$ of Fenoterol were transferred and the total volume of each flask was adjusted to $3 \mathrm{ml}$ by adding water. Then $2 \mathrm{ml}$ each of $\mathrm{FeCl}_{3}(0.2 \%)$ and ferricyanide $(0.2 \%)$ were added to each flask, mixed well and let to stand for $10 \mathrm{~min}$. finally, $1 \mathrm{ml}$ of $10 \mathrm{M} \mathrm{H}_{2} \mathrm{SO}_{4}$ was added to each flask and diluted to mark with water and mixed well. The absorbance of the resulting blue colored solutions were measured at $730 \mathrm{~nm}$ against a reagent blank prepared similarly. The calibration curve representing the relationship between the absorbance and the corresponding concentrations were constructed and the corresponding regression equations were computed.

\section{Analysis of tablets:}

The contents of 10 tablets of Fenoterol were weighed and powdered. A quantity of the powder equivalent to $100 \mathrm{mg}$ was transferred into $100 \mathrm{ml}$ volumetric flask and shaked with $20 \mathrm{ml}$ water for about $10 \mathrm{~min}$. the volumes were adjusted with water and filtered in methods $\mathbf{A}$ and $\mathbf{C}$, while in method $\mathbf{B}$ shaked with $20 \mathrm{ml}$ methanol for about $10 \mathrm{~min}$, and the volume was completed to $100 \mathrm{ml}$ by methanol and filtered. Analysed aliquots of the clear filtrate, labeled to contain $\left(1 \mathrm{mg} \mathrm{ml}^{-1}\right)$, suitably diluted and subjected to procedures $\mathbf{A}, \mathbf{B}$, and C.

\section{RESULTS AND DISCUSSION}

\section{Method A (Diazo-coupling technique):}

The utility of diazotized different amines BZC, SDZ, SCM and SPA as chromogenic reagents for the determination of the phenolic drug was investigated in the present study. The stability of the complex formed maintained by the use of $0.5 \mathrm{ml}$ of $(0.1 \%) \mathrm{BZC},(0.1 \%)$ SDZ, (0.1\%) SCM and (1\%) SPA, as shown in (figure 6), $0.5 \mathrm{ml}$ hydrochloric acid $(0.1 \mathrm{~N})$ in case of BZC and SCM, as shown in (figure 7), $0.5 \mathrm{ml} \mathrm{NaNO} \mathrm{Na}_{2}(1 \%)$ solution, as shown in (figure 8), making the medium alkaline with $0.5 \mathrm{ml} \mathrm{NaOH}(0.2 \mathrm{~N})$ solution, as shown in (figure 9). The reaction mixtures were allowed to stand $5 \mathrm{~min}$. before adjusting volumes with ethanol and measuring the absorbencies at their $\lambda_{\max }$ which were $526,514,512$ and $513 \mathrm{~nm}$ for BZC, SDZ, SCM and SPA, respectively as shown in (Figures 2,3,4,5). The colour intensities were found to be stable for more than one hour, under the optimum experimental conditions. The calibration graphs were constructed for the determination of Fenoterol by the proposed technique where Beer's law was obeyed in the ranges of (10-70), (6-42), (4-28) and (3.5-24.5) $\mu \mathrm{gml}^{-1}$ for (BZC), (SDZ) (SCM) and (SPA), respectively. The stoichimetric ratio determined by molar ratio indicated that the ratio of the drug to reagent is $1: 4$ as shown in (figure 10), the proposed mechanism for the diazo-coupling reaction with BZC is shown in (scheme 1). The regression equations, LOD, LOQ and response factor in addition to A $(1 \%$, $1 \mathrm{~cm}$.) were illustrated in table (1). 
Table (1): Selected spectral data for the determination of Fenoterol by the proposed procedures:

\begin{tabular}{|c|c|c|c|c|c|c|}
\hline \multirow{2}{*}{ Method } & \multicolumn{4}{|c|}{$A$} & \multirow{2}{*}{$\boldsymbol{B}$} & \multirow{2}{*}{$C$} \\
\hline & $\mathrm{BZC}$ & SDZ & SCM & SPA & & \\
\hline$\lambda_{\max } \mathbf{n m}$ & 526 & 514 & 512 & 513 & 619 & 730 \\
\hline $\begin{array}{c}\text { Linearity range } \\
\left(\mu \mathrm{gml}^{-1}\right)\end{array}$ & $10-70$ & $6-42$ & $4-28$ & $3.5-24.5$ & $10-70$ & $1.5-10.5$ \\
\hline $\operatorname{LOD}\left(\mu \mathrm{gml}^{-1}\right)$ & 0.188 & 0.2303 & 0.0586 & 0.0313 & 0.117 & 0.0102 \\
\hline LOQ $\left(\mu g m l^{-1}\right)$ & 0.627 & 0.7678 & 0.1955 & 0.1044 & 0.392 & 0.0343 \\
\hline $\begin{array}{c}\text { Response factor } \\
\pm \text { SD }\end{array}$ & $\begin{array}{c}0.0145 \\
\pm 0.0002 \\
\end{array}$ & $\begin{array}{c}0.0225 \\
\pm 0.0003 \\
\end{array}$ & $\begin{array}{l}0.03546 \\
\pm 0.0004 \\
\end{array}$ & $\begin{array}{c}0.0393 \\
\pm 0.0003 \\
\end{array}$ & $\begin{array}{c}0.0126 \\
\pm 0.0002 \\
\end{array}$ & $\begin{array}{l}0.0907 \\
\pm 0.001 \\
\end{array}$ \\
\hline $\mathrm{A}(1 \%, 1 \mathrm{~cm})$ & 145.04 & 223.78 & 351.5 & 392.23 & 126.37 & 908.33 \\
\hline $\begin{array}{l}\text { Regression } \\
\text { Parameters }\end{array}$ & & & & & & \\
\hline - Slope & 0.01398 & 0.02161 & 0.0343 & 0.0380 & 0.0125 & 0.0903 \\
\hline - Intersept & 0.01325 & 0.01154 & 0.0111 & 0.0105 & 0.0036 & 0.0022 \\
\hline $\begin{array}{c}- \text { Correlation } \\
\text { Coeff }\left(r^{2}\right) \\
\end{array}$ & 0.9997 & 0.9996 & 0.9996 & 0.9996 & 0.9997 & 0.9996 \\
\hline
\end{tabular}

Reaction mechanism was suggested to be as follow:<smiles>CCCC(=O)c1cc(O)cc(N=Nc2cc(O)cc(C(O)CNC(C)Cc3ccc(O)cc3)c2)c1</smiles>

Berzocaine<smiles>CCCC1C=C(NNC2CC=C(C(=O)OCC)CC2)C([O-])=C(NNC2=CC=C(C(=O)OCC)CC2)C1</smiles>

Fenoterol-diazo-compound

Scheme 1: The suggested reaction pathway of Fenoterol with diazotized BZC 


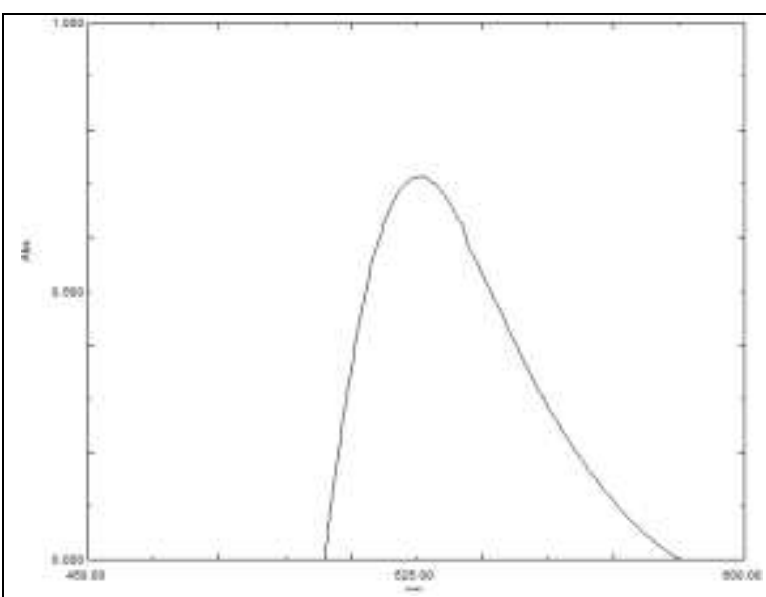

Figure (2): Absorption spectrum of Fenoterol $\left(50 \mu \mathrm{gml}^{-1}\right)$ with Diazotized Benzocain

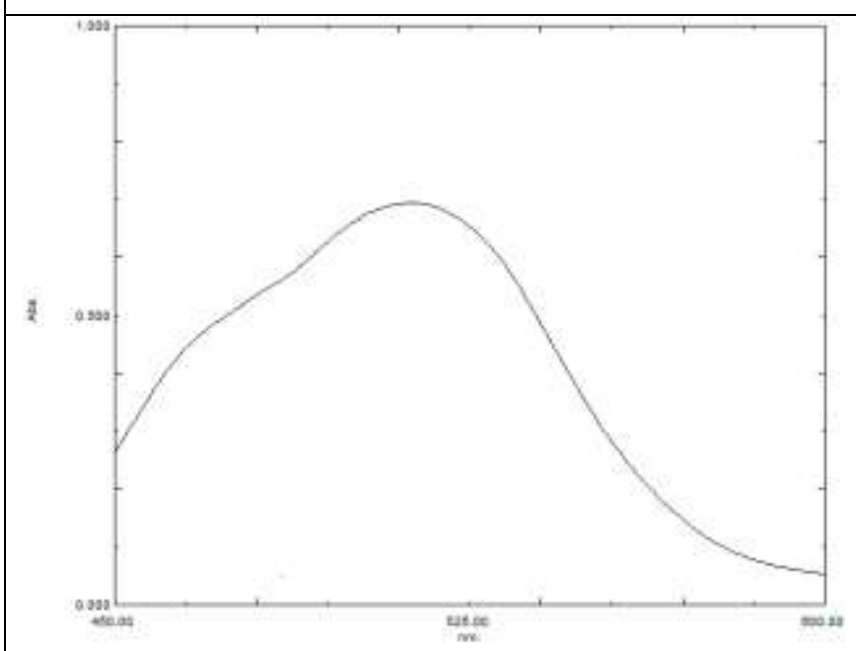

Figure (4): Absorption spectrum of Fenoterol $\left(20 \mu \mathrm{gml}^{-1}\right)$ with Diazotized Sulphacetamide

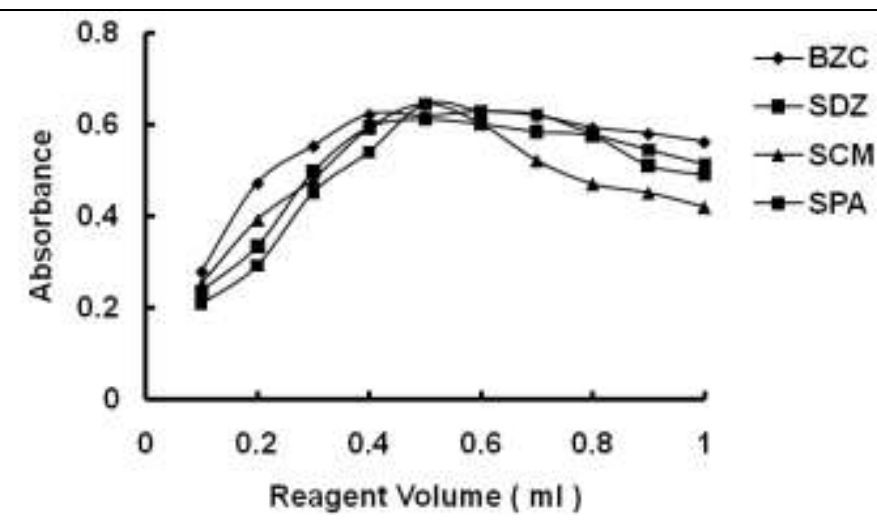

Figure (6) : Effect of volume of amine on absorbance of the formed reaction product with Fenoterol

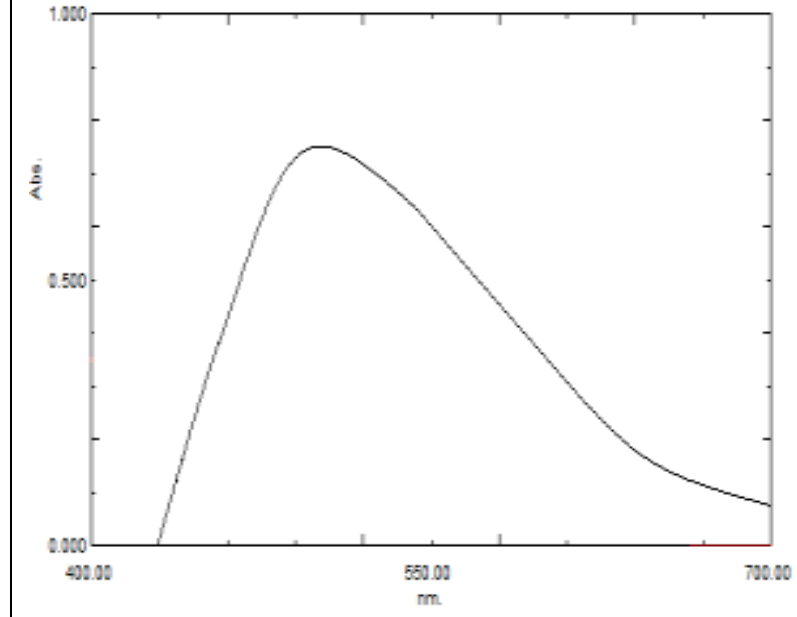

Figure (3): Absorption spectrum of Fenoterol $\left(30 \mu \mathrm{gml}^{-1}\right)$ with Diazotized Sulphadiazine

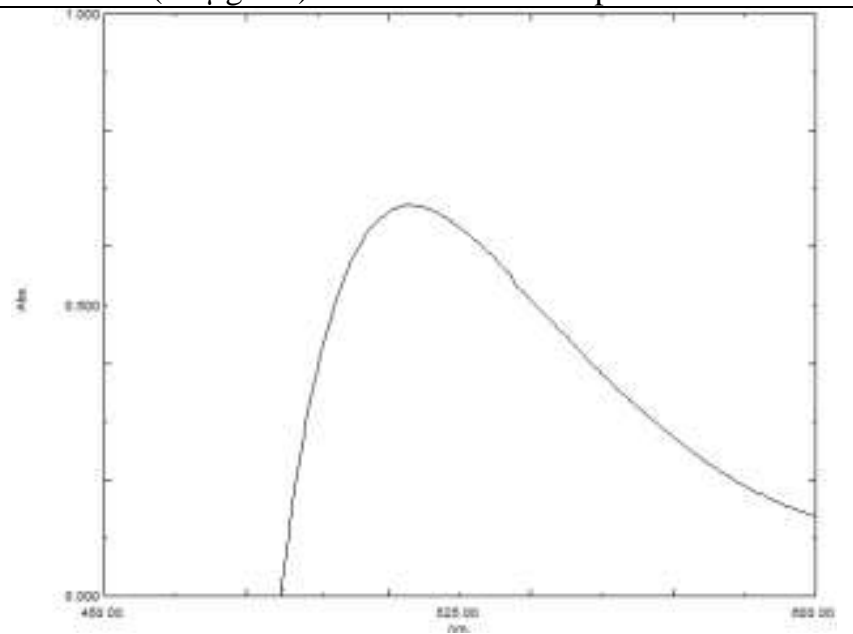

Figure (5): Absorption spectrum of Fenoterol $\left(17.5 \mu \mathrm{gml}^{-1}\right)$ with Diazotized Sulphanilic acid

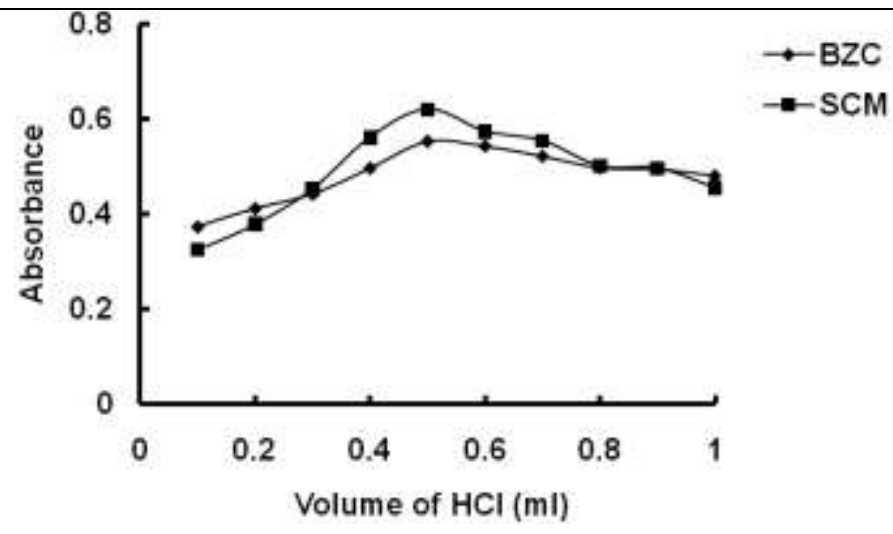

Figure (7): Effect of volume of acid on absorbance of formed reaction product with Fenoterol 


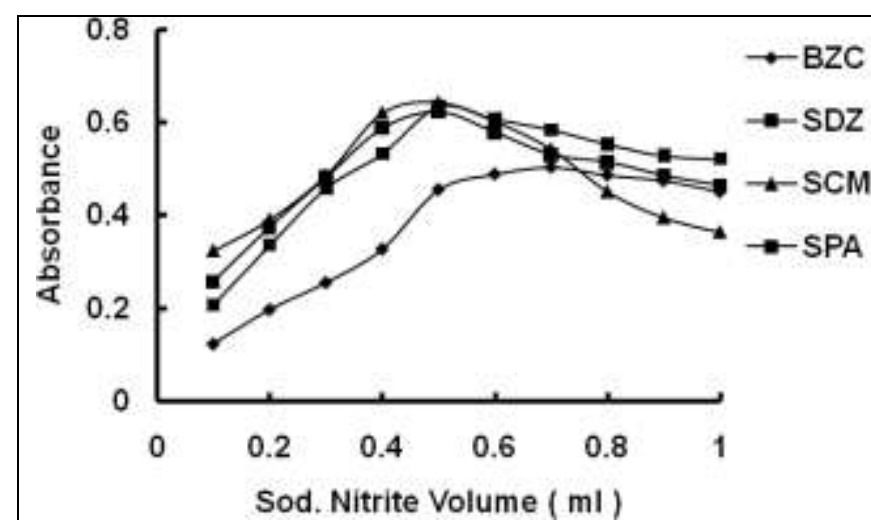

Figure (8): Effect of volume of nitrite on absorbance of the formed reaction product with Fenoterol

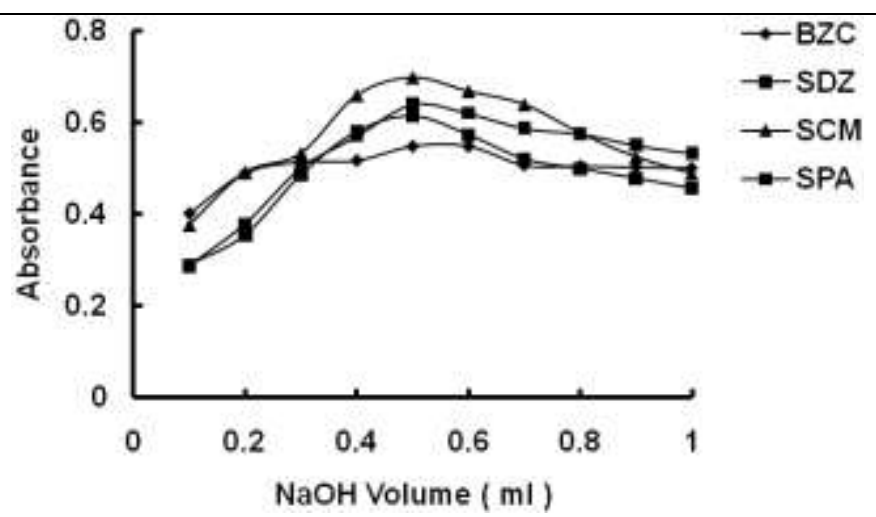

Figure (9): Effect of volume of $\mathrm{NaOH}$ on absorbance of the formed reaction product with Fenoterol

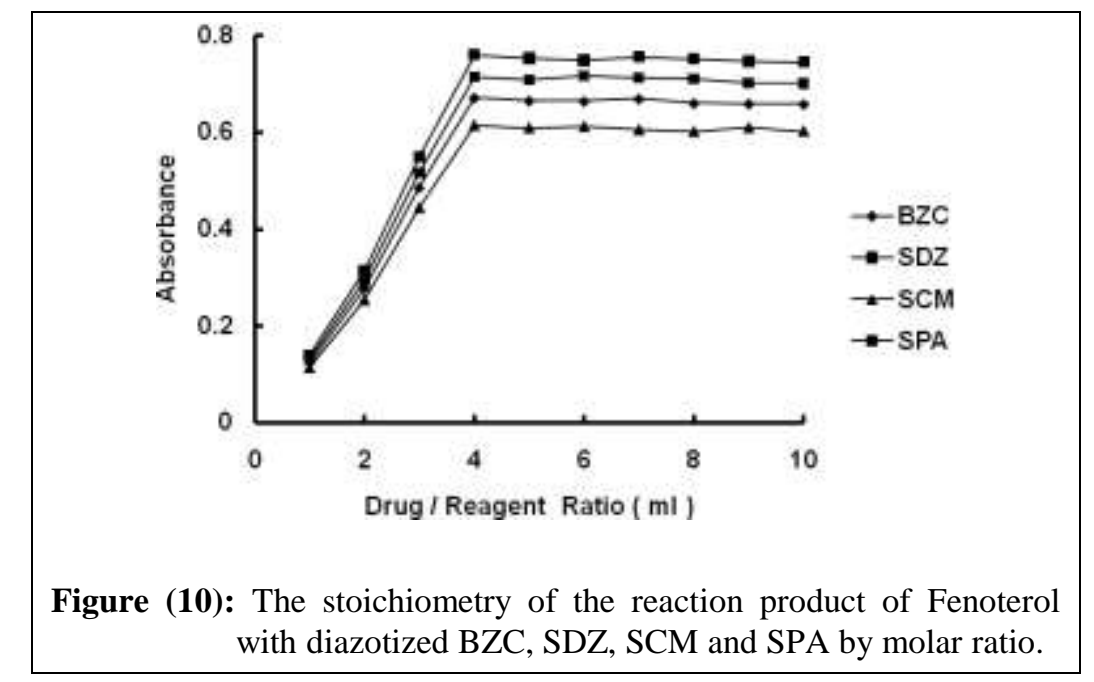

\section{Method B (Ion-pair with cobalt thiocyanat):}

Fenoterol reacted with cobalt (II) thiocyanat to form stable ternary $\left[\mathrm{Co}(\mathrm{SCN})_{4}\right]^{-2}$ complex which could be stabilized by forming ion-pair with similar compounds (Shahine and Khamis, 1983; Cristina and Agustin,1985). This complex was sparingly soluble in aqueous solution, but readily extractable in organic solvents (Shahine and Khamis, 1983). A high concentration of $\left[\mathrm{Co}(\mathrm{SCN})_{4}\right]^{-2}$ was necessary for quantitative complexation, probably due to dissociation in aqueous medium of a fraction of the ion-pair formed (Nerin et al., 1985). It has been found that $4 \mathrm{ml}$ of reagent were sufficient to give best results as shown in (figure 12). Ketones, especially methyl isobutyl ketones, alcohol and all oxygenated solvents, in general, could extract the cobalt (II) thiocyanat as well as its ternary complex (Nerin et al., 1985; Cristina and Agustin, 1985). Slightly polar or non-polar solvents, such as chloroform, methylene chloride, benzene and toluene, extracted only the ion-pair complex (Cristina and Agustin, 1985). Toluene was found to be most convenient solvent as it gave the best results. A single extract of the ternary complex with toluene was sufficient for quantitative extraction. Second extraction gave a colorless organic solution. The blue ionpair complex measured at $\lambda_{\max } 619 \mathrm{~nm}$ (figure 11) and was quite stable for several weeks. The composition of the complex in toluene extract was determined by molar ratio method it was 1:1 for drug : cobalt thiocyanate as shown in (figure 13). The regression equation, LOD, LOQ, response factor and $\mathrm{A}(1 \%, 1 \mathrm{~cm})$ were also recorded in table (1). 


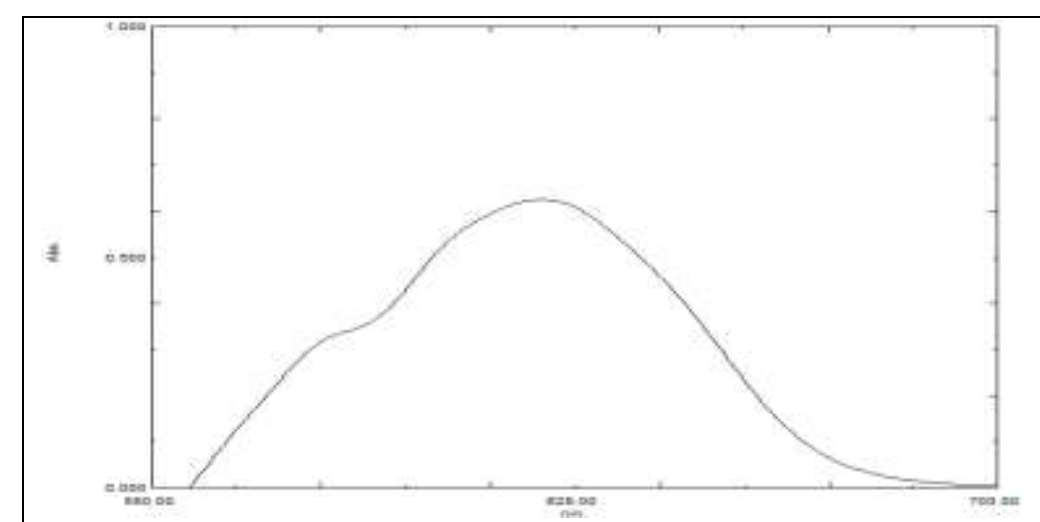

Figure (11): Absorption spectrum of Ion-pair complex formed by Fenoterol $\left(50 \mu \mathrm{gml}^{-1}\right)$ with cobalt thiocyanate

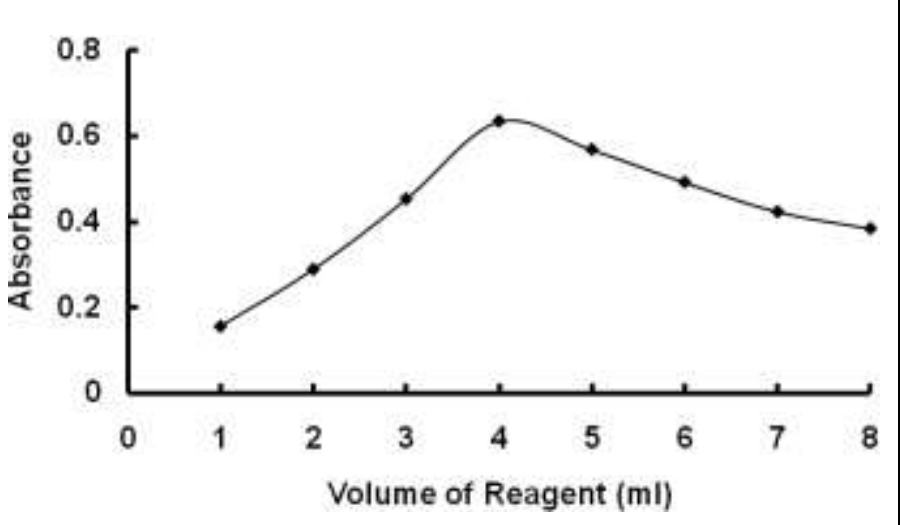

Figure (12) : Effect of $\mathrm{Co}(\mathrm{SCN})_{2}$ volume on the absorbance of the reaction product with Fenoterol

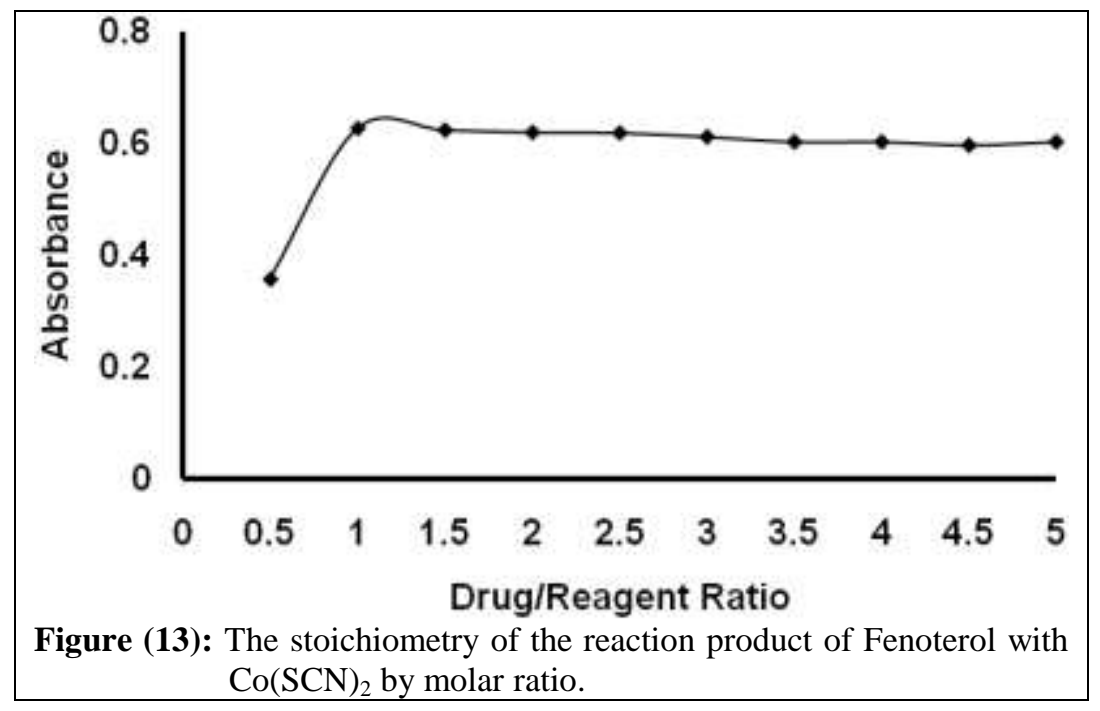

\section{Method C (Purssian blue technique):}

Fenoterol reduce iron (III) to iron (II), the latter reacting with ferricyanide to form intense blue coloured Prussian blue (Pesez and Bartos, 1965) having an absorption maximum at $730 \mathrm{~nm}$. (Figure 14). The optimum conditions were established by the use of 2 $\mathrm{ml} \mathrm{FeCl} 3(0.2 \%)$ as shown in (figure 15$)$ and $2 \mathrm{ml}$ pot. ferricyanide $(0.2 \%)$, as shown in (figure 16). $1 \mathrm{ml}$ of $10 \mathrm{M} \mathrm{H}_{2} \mathrm{SO}_{4}$ was found to give more stable colour and reproducible results compared to hydrochloric acid. It also found that the absorbance increase with time and reaches a maximum in $10 \mathrm{~min}$. as shown in (figure 17) and remained stable for at least 4 hours. The regression equation, LOD, LOQ, response factor and $\mathrm{A}(1 \%, 1 \mathrm{~cm})$ were also recorded in table (1). 


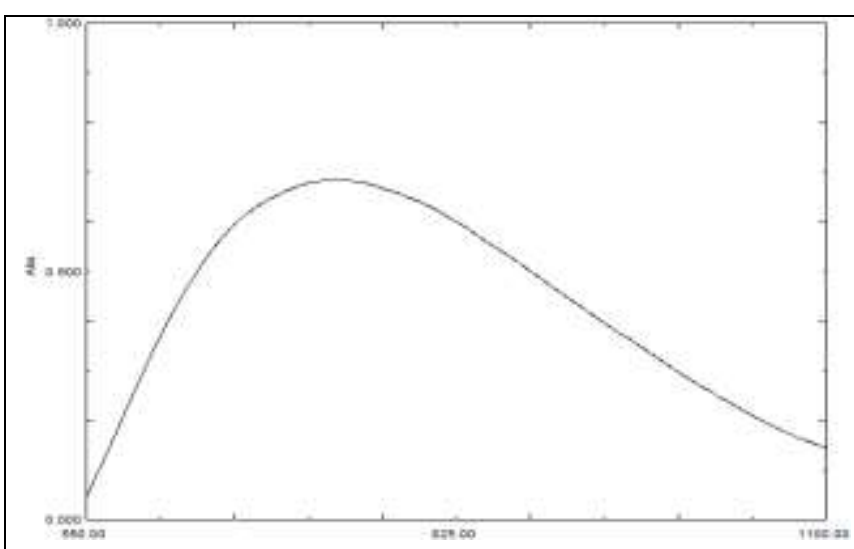

Figure (14): Absorption spectrum of Prussian blue formed by Fenoterol $\left(7.5 \mu \mathrm{gml}^{-1}\right)$ with ferric chloride and potassium ferricyanide.

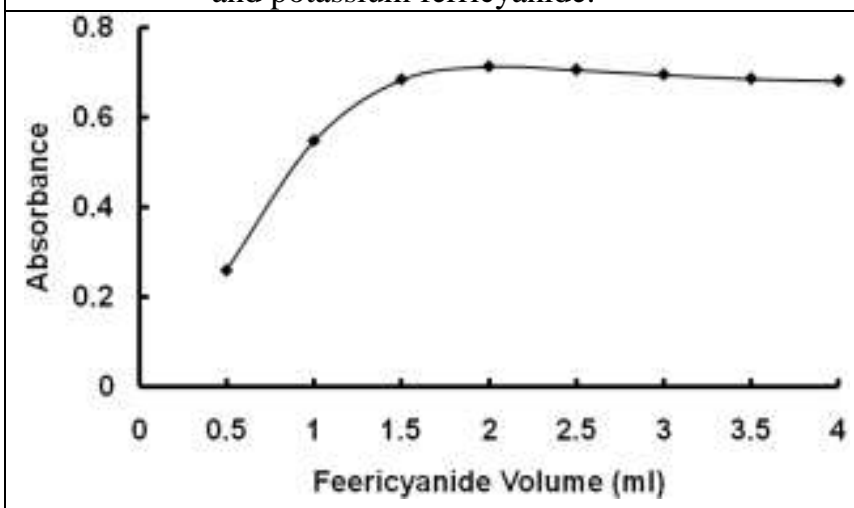

Figure (16): Effect of Ferricyanide volume on the absorbance of the reaction product with Fenoterol.

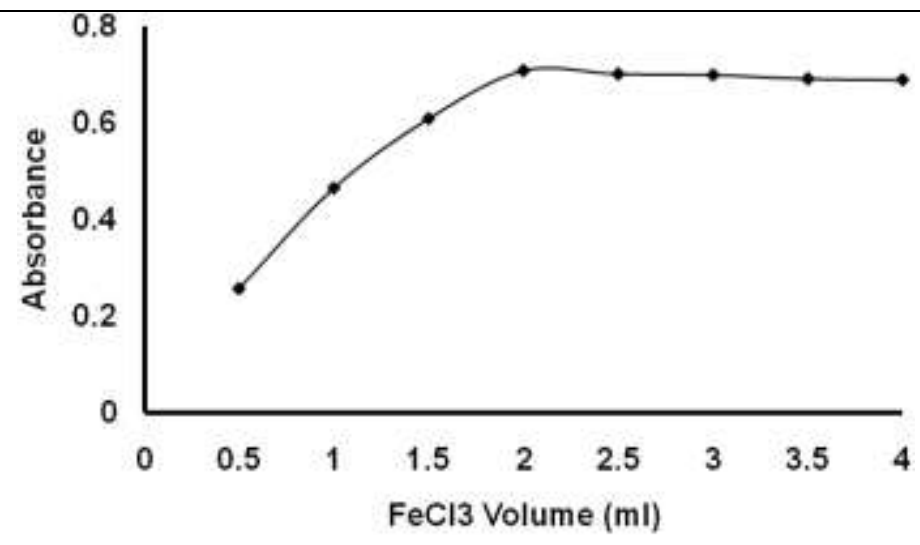

Figure (15): Effect of $\mathrm{FeCl}_{3}$ volume on the absorbance of the reaction product with Fenoterol.

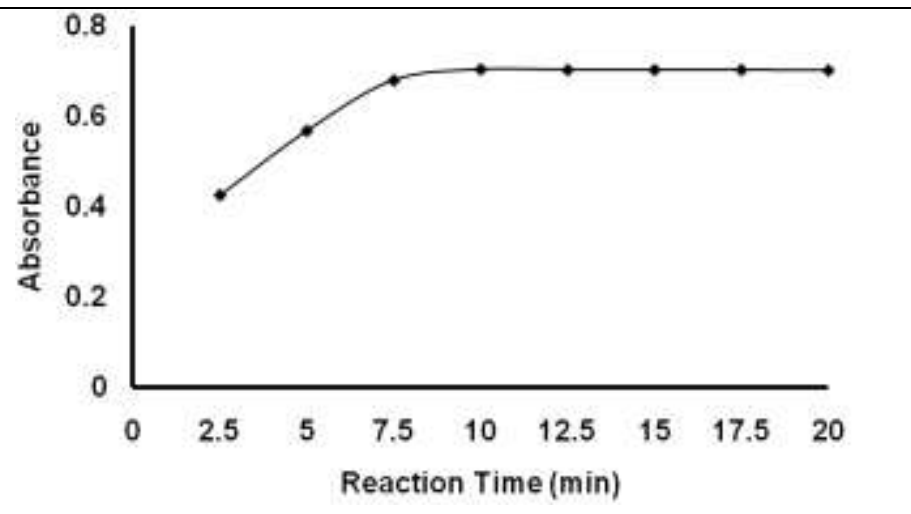

Figure (17): Effect of time on the absorbance of the reaction product of Fenoterol with $\mathrm{FeCl}_{3} /$ Ferricynide reagent.

\section{Validation of the procedures :}

\section{Linearities :}

The linearity range of the drug was validated, where good correlation between the absorbencies and the corresponding drug concentrations for method $\mathbf{A}$ in the range of 10-70, 6-42, 4-28 and 3.5-24.5 $\mu \mathrm{g} \mathrm{ml}^{-1}$, with BZC, SDZ, SCM and SPA, respectively, for method B and $\mathbf{C}$ in the range of $10-70,1.5-10.5 \mu \mathrm{g} \mathrm{ml}^{-1}$, respectively.

\section{LOD and LOQ:}

The experimental LOD and LOQ for the described procedures were determined according to the USP (United States Pharmacopeia, 2000) Table (1).

\section{Accuracy:}

Accuracy was assessed by applying the standard addition technique as shown in tables $(3,4)$.

\section{Precision:}

Intraday and interday precision of the proposed procedures were calculated, table (2) revealed the results of the developed methods. 
Table (2): Intraday ${ }^{*}$ and interday ${ }^{* *}$ accuracy and precision for the determination of Fenoterol by the proposed procedures:

\begin{tabular}{|c|c|c|c|c|c|c|c|c|}
\hline \multirow{2}{*}{\multicolumn{2}{|c|}{ Method }} & \multirow{3}{*}{$\begin{array}{c}\begin{array}{c}\text { Conc. } \\
\text { ugml }^{-1}\end{array} \\
40\end{array}$} & \multicolumn{3}{|c|}{ Intraday } & \multicolumn{3}{|c|}{ Interday } \\
\hline & & & \multirow{2}{*}{$\begin{array}{c}\begin{array}{c}\text { Found } \\
\text { Conc. }+ \text { SD }\end{array} \\
40.05 \pm 0.211\end{array}$} & \multirow{2}{*}{$\begin{array}{c}\begin{array}{c}\text { Accuracy } \\
(\mathbf{R} \%)\end{array} \\
100.12\end{array}$} & \multirow{2}{*}{$\begin{array}{c}\begin{array}{c}\text { Precision } \\
(\boldsymbol{R S D} \%)\end{array} \\
0.297\end{array}$} & \multirow{2}{*}{$\begin{array}{c}\text { Found } \\
\text { Conc. } \pm \text { SD }\end{array}$} & \multirow{2}{*}{$\begin{array}{c}\begin{array}{c}\text { Accuracy } \\
(\mathbf{R} \%)\end{array} \\
100\end{array}$} & \multirow{2}{*}{$\begin{array}{c}\begin{array}{c}\text { Precision } \\
(\boldsymbol{R S D} \%)\end{array} \\
0.356\end{array}$} \\
\hline \multirow{12}{*}{ A } & \multirow{3}{*}{$\underset{N}{\text { U }}$} & & & & & & & \\
\hline & & 50 & $49.93 \pm 0.19$ & 99.89 & 0.236 & $49.9 \pm 0.056$ & 99.80 & 0.441 \\
\hline & & 60 & $60 \pm 0.002$ & 100 & 0.320 & $59.5 \pm 0.06$ & 99.16 & 0.540 \\
\hline & \multirow{3}{*}{ के } & 24 & $24.3 \pm 0.031$ & 101.25 & 0.236 & $24 \pm 0.036$ & 100 & 0.435 \\
\hline & & 30 & $29.9 \pm 0.061$ & 100.55 & 0.670 & $36.32 \pm 0.043$ & 100.88 & 0.551 \\
\hline & & 36 & $36.2 \pm 0.022$ & 99.66 & 0.181 & $30 \pm 0.061$ & 100 & 0.281 \\
\hline & \multirow{3}{*}{$\sum_{W}$} & 16 & $16.6 \pm 0.051$ & 100.37 & 0.213 & $16 \pm 0.025$ & 100 & 0.312 \\
\hline & & 20 & $19.9 \pm 0.025$ & 99.5 & 0.203 & $20 \pm 0.046$ & 100 & 0.196 \\
\hline & & 24 & $24.02 \pm 0.045$ & 100.08 & 0.187 & $24.02 \pm 0.045$ & 100.08 & 0.342 \\
\hline & \multirow{3}{*}{$\overleftrightarrow{\omega}$} & 14 & $14.18 \pm 0.031$ & 101.33 & 0.181 & $14 \pm 0.062$ & 100 & 0.281 \\
\hline & & 17.5 & $17.2 \pm 0.002$ & 98.5 & 0.297 & $17.23 \pm 0.016$ & 98.5 & 0.356 \\
\hline & & 21 & $21 \pm 0.064$ & 100 & 0.245 & $21 \pm 0.102$ & 100 & 0.437 \\
\hline \multirow{3}{*}{\multicolumn{2}{|c|}{ B }} & 40 & $40 \pm 0.141$ & 100 & 0.354 & $39.92 \pm 0.056$ & 99.8 & 0.144 \\
\hline & & 50 & $50.05 \pm 0.020$ & 100.1 & 0.450 & $50 \pm 0.032$ & 100 & 0.435 \\
\hline & & 60 & $60.03 \pm 0.002$ & 100.05 & 0.221 & $59.93 \pm 0.003$ & 99.88 & 0.134 \\
\hline \multirow{3}{*}{\multicolumn{2}{|c|}{ C }} & 4.5 & $4.48 \pm 0.013$ & 99.55 & 0.201 & $4.53 \pm 0.071$ & 100.66 & 0.351 \\
\hline & & 6 & $6.08 \pm 0.002$ & 101.30 & 0.532 & $6 \pm 0.002$ & 100 & 0.563 \\
\hline & & 7.5 & $7.5 \pm 0.001$ & 100 & 0.170 & $7.5 \pm 0.002$ & 100 & 0.171 \\
\hline
\end{tabular}

$* \mathrm{n}=4$

$* * \mathrm{n}=3$ 
Table (4): Application of standard addition technique for the determination of Fenoterol in its pharmaceutical preparation by Ion-pair, and Prussian blue techniques.

\begin{tabular}{|c|c|c|c|c|c|}
\hline \multicolumn{3}{|c|}{ Method B } & \multicolumn{3}{c|}{ Method C } \\
\hline $\begin{array}{c}\text { Claimed taken } \\
\left(\mu \mathrm{gml}^{-1}\right)\end{array}$ & $\begin{array}{c}\text { Pure added } \\
\left(\mu \mathrm{gml}^{-1}\right)\end{array}$ & $\begin{array}{c}\text { Recovery* \% of } \\
\text { pure added }\end{array}$ & $\begin{array}{c}\text { Claimed taken } \\
\left(\mu \mathrm{gml}^{-1}\right)\end{array}$ & $\begin{array}{c}\text { Pure } \\
\text { added } \\
\left(\mu \mathrm{gml}^{-1}\right)\end{array}$ & $\begin{array}{c}\text { Recovery* \% of } \\
\text { pure added }\end{array}$ \\
\hline \multirow{3}{*}{20} & 20 & 99.2 & & 3 & 100.16 \\
\cline { 2 - 3 } & 30 & 98.19 & \multirow{2}{*}{3} & 4.5 & 98.65 \\
\cline { 2 - 3 } & 40 & 99.3 & & 6 & 99.10 \\
\cline { 2 - 3 } & 50 & 98.4 & & 7.5 & 99.7 \\
\hline Mean & & 98.1 & & & 99.5 \\
\hline SD & & \pm 0.57 & & & \pm 0.66 \\
\hline
\end{tabular}

$* \mathrm{n}=5$

\section{Specificity:}

Owing to the phenolic character of the drug investigated, the reaction was found to be specific for Fenoterol. It was also shown that excipients and diluents do not interfere with the proposed procedures.

\section{Stability of standard solutions:}

The stability of Fenoterol solution was evaluated by analysis of aqueous solutions of Fenoterol which was found to be stable for 7 days at room temperature and 3 weeks in refrigerator.

\section{Analysis of pharmaceutical preparations:}

The proposed procedures were also adopted for the determination of Fenoterol in Berotc $^{\circledR}$ tablets. It should be pointed out that no interference by excipients and additives in Berotc $^{\circledR}$ tablets. The recovery of the proposed methods was assured by applying the standard addition technique (Table 3,4). The results obtained by the proposed procedures were statistically compared with those obtained by the reported spectrophotometric methods (Negussie et al., 2004) after reaction with 4-aminoantipyrine. The data in Table 5 shows that the calculated " $t$ " and " $F$ " values are less than the tabulated ones, indicating no significant difference between the proposed methods and reported one, confirming accuracy and precision at $95 \%$ confidence limits. 
Table (5): Statistical analysis of results obtained by the proposed and reported methods for the determination of Fenoterol in its pharmaceutical preparatio

\begin{tabular}{|c|c|c|c|c|c|c|c|}
\hline \multirow{2}{*}{ Methods } & \multicolumn{4}{|c|}{ A } & \multirow{2}{*}{ B } & \multirow{2}{*}{$C$} & \multirow{2}{*}{$\begin{array}{c}\text { Reported } * * * \\
\text { Method }\end{array}$} \\
\hline & $B Z C$ & $S D Z$ & $S C A$ & $S P A$ & & & \\
\hline$N^{*}$ & 7 & 7 & 5 & 5 & 6 & 5 & 5 \\
\hline Mean & 99.94 & 99.72 & 100.26 & 99.8 & 99.45 & 99.31 & 100.60 \\
\hline SD & 1.26 & 0.29 & 1.4 & 0.62 & 0.62 & 0.62 & 0.77 \\
\hline$R S D \%$ & 1.26 & 0.29 & 1.4 & 0.62 & 0.62 & 0.62 & 0.77 \\
\hline $\mathbf{t}^{* *}$ & $\begin{array}{c}0.76 \\
(1.79)\end{array}$ & $\begin{array}{c}0.80 \\
(1.83)\end{array}$ & $\begin{array}{c}0.70 \\
(1.83)\end{array}$ & $\begin{array}{c}0.24 \\
(1.81)\end{array}$ & $\begin{array}{c}1.29 \\
(1.83)\end{array}$ & $\begin{array}{c}1.97 \\
(2.31)\end{array}$ & \\
\hline $\mathbf{F}^{* *}$ & $\begin{array}{c}1.29 \\
(4.95)\end{array}$ & $\begin{array}{c}1.42 \\
(6.26)\end{array}$ & $\begin{array}{c}1.06 \\
(6.26)\end{array}$ & $\begin{array}{c}1.9 \\
(6.16)\end{array}$ & $\begin{array}{c}2.01 \\
(6.26)\end{array}$ & $\begin{array}{c}2.37 \\
(6.16)\end{array}$ & \\
\hline
\end{tabular}

$*$ Number of experimental.

** The values in parenthesis are tabulated values for " $\mathrm{t}$ " and " $\mathrm{F}$ " at $\mathrm{P}<0.05$.

*** The reported method involves spectrophotometric method (3)

\section{CONCLUSION :} method.

The proposed methods are simpler, faster, and more sensitive than the reported

\section{REFERENCE:}

Belal, F; Al-Malag, H A; and Al-Majed, A. A. (2000): J. Pharma. Bio. Analysis, (23) $1005-1015$.

Cristina, N; and Agustin, G. (1985): Analytical Chem, 57, 34.

Danuta, S; Hee Seung. K; Tyler. C; and Trving, W W. (2008): J. Pharma. Bio. Analysis, (48) 960-964.

El-Shabrawy, Y; Belal, F; Shaaf, M; El-Din and Shalan Sh. (2003): Farmaco., 58 (2) 1033-1038.

El-Tarras, M F; Rizk, S M; Toubar, S. and Balia, M A. (2005): Anal. Lett. (54) 442-448.

Hee Seung, K; Danuta, S; and Irving, W. W. (2008): J. Chromato. A. 46 (8).

Ingolfe, M; Hannelore, S; Skaidrit and Christoph, H. G. (2002): J. Pharam. Bio Analysis, (29) 147-152.

Kathleen, $\boldsymbol{P}$. (1999): Martindale the complete drug reference 32 ed.

Manal, E. (2007): J. Chines. Chem. Soc., (54) 613-617.

Negussie, W. B; Jocobus, F S and Raluca, I S. (2004): Anal. Chemica. Acta., (521) 223-229.

Nerin, C J C; and Garina, A. (1985): Anal.Letters, 18, B15. 1887.

Pesez, M; Bartos, J. (1965): Ann. Pharm. Fr., 218. 
Rose J. (1964): "Advanced physico-chemical Experiments" Pitman London.

Shahine, S; and Khamis, S. (1983): J. Microchem, 28.

Somsak, S. and Proespichaya, Kh. (2008): Talanta., (76) 1194-1198.

United States Pharmacopeia (2000): 24, NF 19,Siar Ed., Rand, Me. Nally USA.

Zamuner, M L M; Carrion, C E; and Magalhaes, J F. (2008): Rev. Bras. Cien.

Farm, 44 (4) 645-653.

$$
\begin{aligned}
& \text { تعيين فينوتيرول بأستخدام ثلاث طرق طيف ضوئية مختلفة } \\
& \text { منير عبدالسميع أمين ، فتحى محمود سلامة ، محمد وفاء ابراهيم، ،الصديق عبد الله عبيد* ، سمير مرشدى مرشدي }
\end{aligned}
$$

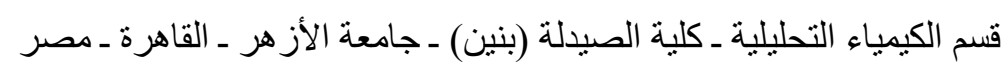

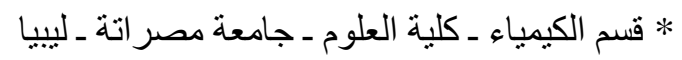

$$
\begin{aligned}
& \text { فى هذا البحث تم استتباط ثناث طرق طيف ضوئية للتعيين الكمى لعقار فينوتيرول هيدروكلوريد سواء في }
\end{aligned}
$$

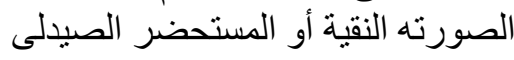

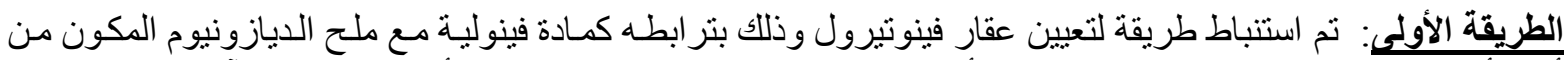

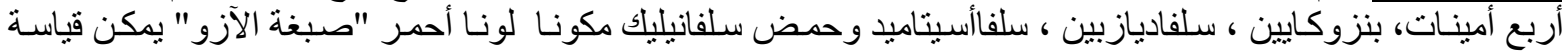

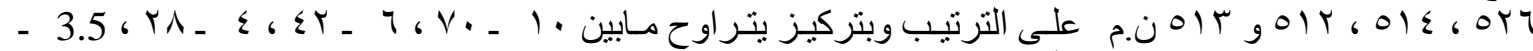

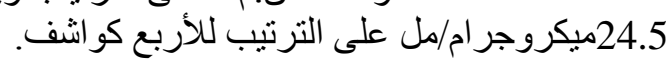

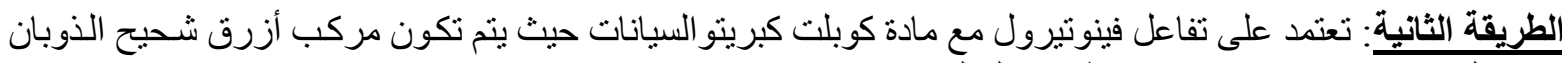

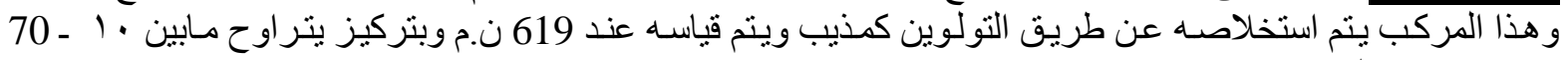

$$
\begin{aligned}
& \text { ميكروجر ام / مل. ملن. }
\end{aligned}
$$

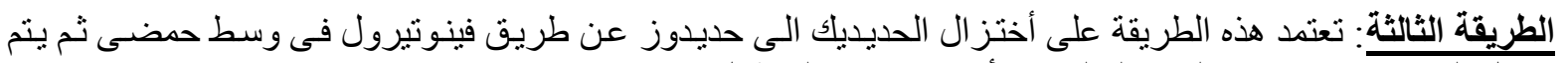

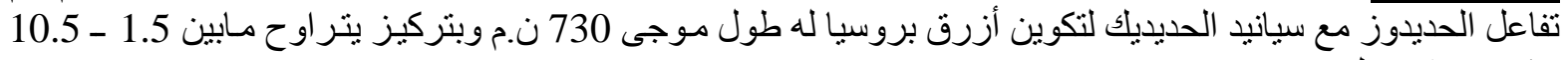

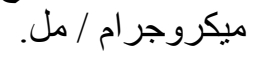


